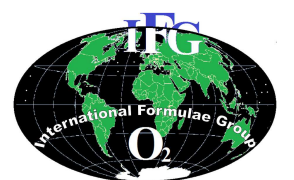

\title{
A comparative study of the hematological values in the ovulation and luteal phases of the menstrual cycle
}

\author{
A. OMOROGIUWA* and E. E. EGBELUYA \\ Department of Physiology, School of Basic Medical Sciences, College of Medical Sciences, \\ University of Benin, Nigeria. \\ "Corresponding author, E-mail: ask4ade2006@yahoo.com; Tel: +234(0)7039460340
}

\begin{abstract}
ABSRACT
This study compares the hematological values of the ovulation phase with the luteal phase of the menstrual cycle. Sixty subjects with 30 subjects each in the ovulation and luteal phases of the menstrual cycle were studied. Ethical clearance and informed consent were obtained for the study. Hematological parameters of blood samples collected using aseptic technique were analysed using the Swelab Alfa automatic hematology analyser. Granulocyte $\left(\times 10^{3} / \mu \mathrm{L}\right)$ value for the ovulation and luteal phases were $1.48 \pm 0.15$ and $2.53 \pm 0.36$ respectively $(\mathrm{p}<0.05)$. The Granulocyte\% for the ovulation and luteal phases were $33.34 \pm 2.46$ and $45.81 \pm 2.93$ respectively $(\mathrm{p}<0.05)$. The Lymphocyte $\%$ for ovulation and luteal phases were $58.89 \pm 1.66$ and $47.58 \pm 2.76$ respectively $(\mathrm{p}<0.05)$. The Mean platelet volume values for ovulation and luteal phases were $7.68 \pm 0.30$ and $8.06 \pm 0.31$ respectively $(\mathrm{p}<0.001)$. The plateletcrit for ovulation and luteal phases were $0.14 \pm 0.02$ and $0.15 \pm 0.02$ respectively $(\mathrm{p}<0.001)$. The Platelet Width Density for ovulation and luteal phases were $11.53 \pm 0.49$ and $12.13 \pm 0.48$ respectively ( $<<0.01$ ). The Platelet Larger Cell Ratio for ovulation and luteal phases were $15.46 \pm 1.82$ and $18.04 \pm 1.78$ respectively $(\mathrm{p}<0.01$ ). Red cell parameters remained unchanged in both phases of the menstrual cycle. Platelet and granulocyte parameters are the hematological changes observed in the ovulation phase when compared to the luteal phase.
\end{abstract}

(C) 2014 International Formulae Group. All rights reserved.

Keywords: Ovulation, luteal phase, menstrual cycle, hematological.

\section{INTRODUCTION}

The menstrual cycle connotes a series of utero-ovarian and hormonal events that occur in fertile women and other primates for the purpose of procreation. It is counted from the first day of menstrual bleeding and ends when the next period begins. It is divided into four phases: the menstruation phase, follicular phase, ovulation phase, and the luteal phase. The follicular phase is also called the proliferative phase because some hormones causes the lining of the uterus to grow, or proliferate, during this time. Through the influence of a rise in follicle stimulating hormone (FSH) during the first days of the cycle, a few ovarian follicles are stimulated. Ovarian follicles are present at birth and develop for the better part of a year in a process known as folliculogenesis. These follicles subsequently compete with each other for dominance (Losos et al., 2002). Ovulation is the event of the Graaffian's follicle rupturing and releasing a mature ovum, which is picked by the fimbriae end of the oviduct. It usually occurs regularly, around day 14 of a 28-day menstrual cycle. 
Once released, the egg is capable of being fertilized for 20 to 24 hours before it begins to disintegrate (Young, 2006). It is the few days around ovulation that a woman is most fertile. The luteal phase is also called the secretory phase. During the luteal phase, the corpus luteum which is a solid body formed in the ovary after the egg has been released from the ovary continues to grow and produces significant amounts of hormones, particularly progesterone (Losos et al., 2002). Progesterone plays a vital role in making the endometrium receptive to implantation of the blastocyst and supportive of the early pregnancy. Besides, the rise in basal body temperature caused by progesterone can be used to predict ovulation (Weschler, 2002). Overall the menstrual cycle is characterized by cyclical fluctuations in the levels of Follicle stimulating hormone (FSH), Luteinizing hormone (LH), estrogen and progesterone. These fluctuations can affect hematological parameters. For instance, platelet function is periodically altered during the ovarian cycle due to the influence of progesterone and estrogen on Von Willebrand factor concentrations (Drici et al., 1996). Ovarian hormones also alter the immune system like depression of the suppressor T cell activity (Dixon et al., 1994). Human \& animal studies suggest that there is a change in the distribution of immune cells during different phases of menstrual cycle (Pehlivanoglu et al., 2001). The ovulation phase of the menstrual cycle is the marker for fertilization and it may have unique hematological values. This study compares the hematologic values in the ovulation and luteal phases of the menstrual cycle.

\section{MATERIALS AND METHODS}

Sixty (60) healthy female undergraduates with a 28 day menstrual cycle were studied. Thirty (30) of the subjects were in the late luteal phase while 30 subjects were in the ovulation phase of the menstrual cycle.

\section{Ethical clearance}

Informed consent and ethical approval were obtained from the Research and Ethics Committee of St Philomenas Catholic Hospital.

\section{Methodology \\ Blood samples were collected under aseptic conditions from the ante-cubital vein by venepuncture into a specimen bottle containing the anticoagulant Ethylene Diamine Tetra acetic Acid (EDTA). Blood samples were analysed within 1-2 hours of collection using the Swelab Alfa automatic hematology analyser.}

\section{Data analysis}

Red cell, white cell and platelet indices in the ovulation and luteal phases of the menstrual cycle were recorded and statistical analysis was done using the Student's t-test, $\mathrm{p}<0.05$ was considered significant.

\section{RESULTS}

In general, there was no statistical difference $(p>0.05)$ in all red blood cell indices of the ovulation phase compared to the luteal phase of the menstrual cycle. However, the granulocyte, granulocyte percentage and lymphocyte percentage showed a significant difference $(p<0.05)$ between these two phases of the menstrual cycle. Furthermore, platelet indices such as the Plateletcrit, Platelet width density and Platelet larger cell ratio of the ovulation phase was statistically different $(p<0.05)$ from that of the luteal phase.

\section{Red cell indices}

The red cell indices considered for both the ovulation and luteal phases of the menstrual cycle are shown in Table 1. The reductions in values of Red Cell Count, Mean Corpuscular Volume Cell, Red Density width and Hematocrit luteal phase when compared to the values in the ovulation phase were only empirical, there was no statistical difference $(p>0.05)$ between the values of these two phases of the menstrual cycle. 


\section{White Blood cell indices}

The variation in the white cell indices of the ovulation phase when compared to the luteal phase is shown in Table 2. From this table, it is shown that there was a statistically significant $(\mathrm{p}<0.05)$ rise in granulocyte count $\left(2.53 \pm 0.36 \times 10^{3} / \mu \mathrm{L}\right)$ of the luteal phase when compared to that $\left(1.48 \pm 0.15 \times 10^{3} / \mu \mathrm{L}\right)$ of the ovulation phase of the menstrual cycle. As shown in table, there was also a statistically significant rise in the granulocyte percentage $(45.81 \pm 2.93)$ of the luteal phase when compared to that $(33.34 \pm 2.46)$ of the ovulation phase. Although the luteal phase $\left(2.54 \pm 0.25 \times 10^{3} / \mu \mathrm{L}\right)$ decrease in lymphocyte count was not statistically different $(\mathrm{p}>0.05)$ from the ovulation value $\left(2.70 \pm 0.23 \times 10^{3} / \mu \mathrm{L}\right)$ the lymphocyte percentage $(58.89 \pm 1.66)$ for the ovulation phase was statistically higher $(\mathrm{p}<0.05)$ than that of the luteal phase $(47.58$ $\pm 2.76)$.

\section{Platelet indices}

The platelet count and platelet indices of the ovulation and luteal phases of the menstrual cycle are shown in Table 3. Overall, the platelet count $\left(196.80 \pm 23.46 \times 10^{3} / \mu \mathrm{L}\right)$ for the luteal phase was not statistically different $(p>0.05)$ from that $(186.10 \pm 18.54$ $\left.\mathrm{x} 10^{3} / \mu \mathrm{L}\right)$ of the ovulation phase. However, the platelet indices for the luteal phase compared to the ovulation phase showed statistical difference $(\mathrm{p}<0.05)$.

Table 1: Red blood cell and related indices during the luteal and ovulation phases of the menstrual cycle.

\begin{tabular}{lcccc}
\hline Parameter & Ovulation phase & Luteal phase & t-value & p-value \\
\hline Red Blood Cell $\left(\times 10^{6} / \mu \mathrm{L}\right)$ & $4.95 \pm 0.16$ & $4.92 \pm 0.20$ & 0.19 & 0.85 \\
Mean Corpuscular Volume (fL) & $80.63 \pm 2.72$ & $79.58 \pm 2.56$ & 1.02 & 0.34 \\
Red Density width (fL) & $59.76 \pm 2.21$ & $59.06 \pm 1.94$ & 0.46 & 0.66 \\
Hematocrit $(\%)$ & $39.76 \pm 1.33$ & $39.05 \pm 1.72$ & 0.56 & 0.59 \\
Hemoglobin(g/dL) & $10.97 \pm 0.46$ & $11.03 \pm 0.36$ & 0.67 & 0.52 \\
Mean Corpuscular hemoglobin & $22.25 \pm 0.93$ & $22.67 \pm 0.95$ & 0.95 & 0.37 \\
(pg) & & & \\
Mean Corpuscular hemoglobin & $27.52 \pm 0.41$ & $28.47 \pm 0.70$ & 1.20 & 0.26 \\
concentration (g/dL) & & & \\
\hline$* \mathrm{p}<0.05$ Considered significant different in ovulation and luteal phase. & & &
\end{tabular}

Table 2: White Blood cell and related indices during the ovulation and luteal phases of the menstrual cycle.

\begin{tabular}{lcccc}
\hline Parameter & Ovulation phase & Luteal phase & t-value & p-value \\
\hline White blood cell $\left(\mathrm{x} 10^{3} / \mu \mathrm{L}\right)$ & $4.59 \pm 0.33$ & $5.51 \pm 0.51$ & 1.87 & 0.10 \\
Lymphocyte $\left(\mathrm{x} 10^{3} / \mu \mathrm{L}\right)$ & $2.70 \pm 0.23$ & $2.54 \pm 0.25$ & 0.46 & 0.66 \\
Granulocyte $\left(\mathrm{x} 10^{3} / \mu \mathrm{L}\right)$ & $1.48 \pm 0.15$ & $2.53 \pm 0.36$ & 2.59 & $0.03^{*}$ \\
Lymphocyte percentage & $58.89 \pm 1.66$ & $47.58 \pm 2.76$ & 3.14 & $0.01^{*}$ \\
Granulocyte percentage & $33.34 \pm 2.46$ & $45.81 \pm 2.93$ & 3.18 & $0.01^{*}$ \\
Mid sized cells $\left(\mathrm{x} 10^{3} / \mu \mathrm{L}\right)$ & $0.41 \pm 0.06$ & $0.44 \pm 0.08$ & 1.78 & 0.11 \\
Mid sized cells percentage & $7.77 \pm 1.40$ & $6.61 \pm 0.93$ & 1.47 & 0.18 \\
\hline
\end{tabular}

$* \mathrm{p}<0.05$ Considered significant different in ovulation and luteal phase. 
Table 3: Platelets parameters and related indices during the ovulation and luteal phases of the menstrual cycle.

\begin{tabular}{lllcc}
\hline Parameter & Ovulation phase & Luteal phase & t-value & p-value \\
\hline Platelet $\left(\mathrm{x} 10^{3} / \mu \mathrm{L}\right)$ & $196.80 \pm 23.46$ & $186.10 \pm 18.54$ & 0.91 & 0.39 \\
Mean platelet volume (fL) & $7.68 \pm 0.30$ & $8.06 \pm 0.31$ & 5.28 & $<0.001^{*}$ \\
Platecrit $(\%)$ & $0.14 \pm 0.02$ & $0.15 \pm 0.02$ & 9.00 & $<0.001^{*}$ \\
Platelet width density (fL) & $11.53 \pm 0.49$ & $12.13 \pm 0.48$ & 3.66 & $0.01^{*}$ \\
Platelet larger cell ratio & $15.46 \pm 1.82$ & $18.04 \pm 1.78$ & 4.22 & $0.002^{*}$ \\
\hline
\end{tabular}

${ }^{*} \mathrm{p}<0.05$ Considered significant different in ovulation and luteal phase.

\section{DISCUSSION}

The menstrual cycle is characteristically divided into four phases namely the menstruation, follicular, ovulation and luteal. Each of these phases has unique features. For instance, the menstrual phase is characterized by bleeding, the follicular phase is characterized by the ultimate growth of a graffian follicle, ovulation is characterized by the release of the ovum, while the luteal phase is characterized by the preparation of the reproductive organs for pregnancy. These phases may also have their characteristic hematological features. This study is restricted to the ovulation and luteal phases of the menstrual cycle. The red blood cell count, mean cell volume, red density width, hematocrit, hemoglobin concentration, mean corpuscular hemoglobin and mean cell hemoglobin concentration were essentially the same in the ovulation and luteal phases of the menstrual cycle. This is not unexpected because these phases of the menstrual cycle do not involve hemorrhage. However, Rajnee et al. (2010) reported that hemoglobin concentration might increase from menstrual phase to secretory phase due to increased erythropoiesis to compensate for the blood loss during menses. Hemoglobin and red blood cell count have been reported to increase from the early menstrual phase until the post-ovulatory period, with a subsequent decrease towards the end of the cycle (Harewood et al., 2000; Kim et al., 1993). Some studies showed that hemoglobin concentrations were significantly lower in follicular phase than in the luteal phase (Simmons and Butterworth, 1997; Loraine and Bell, 1963). In the present study, the total WBC count and the lymphocyte count showed no changes in the ovulation phase when compared to the luteal. This is consistent with previous studies (Pathak et al., 1981; Pohle, 1939; Makinoda et al., 1996). This study revealed that the granulocyte was higher in the luteal phase when compared to the ovulation phase and this is conisitent with previous studies (Mathur et al., 1979). Estrogen seems to enhance granulocyte proliferation in vitro and probably promotes the release of neutrophil from the bone marrow rather than from the marginated pool (Bain and England, 1975). In the present study, significant increase was observed in Granulocyte and Granulocyte\% in luteal phase compared to the ovulation phase. Significant increase was also observed on Lymphocyte percentage in ovulation phase compared to luteal phase. Study showed increase in differential lymphocyte count during proliferative \& secretory phase in comparison to menstrual phase probably due to increase in number of Helper T cells, cytotoxic $\mathrm{T}$ cells \& Natural killer cells (Faas et al., 2000), that occurs under the influence of steroids. This study also revealed that platelet indices mean platelet volume, plateletcrit, platelet density width and platelet larger cell ratio showed significant increase in luteal phase compared to ovulation phase. This may be induced by 
phasic changes in female sex steroids, endometrial shedding, blood loss and inflammatory-like process during ovulation and shifting of immune response from type 1 to type 2 during the luteal phase (Dixon et al., 1994). Studies also indicate that platelet function is periodically altered during menstrual cycle due to the influence of progesterone and estrogen on Von Willebrand factors concentration (Feuring et al., 2002).

\section{Conclusion}

We conclude that granulocyte, granulocyte percentage, mean platelet volume, plateletcrit, platelet width density and platelet larger cell ratio are significantly lower in the ovulation phase when compared to the luteal phases of the menstrual cycle. Whereas lymphocyte percentage was significantly higher in the ovulation phase compared to the luteal phase. This observation may be induced by phasic changes in female sex steroids and immune response.

\section{REFERENCES}

Bain BJ, England JM. 1975. Variations in leucocyte count during menstrual cycle. Br. Med. J., 2: 473-475.

Bouman A, Moes H, Heineman MJ, De Leij LF, Faas MM. 2001. The immune responses during the luteal phase of the ovarian cycle: increasing sensitivity of human monocytes to endotoxin. Fertile steril., 76: 555-559.

Dixon AL, Rutter SM, Peterson CM.1994. Cyclic changes in the concentration of immune cells during the normal menstrual cycle. Physiological Society of Experimental Biology and Medicine, 27: 81-88.

Drici MD, Burklow TR, Haridasse V. 1996. Sex hormones prolong the QT interval and downregulate potassium channel expression in the rabbit heart. Circulation, 94: 1471-1474.

Faas MM, Bouman A, Moes H, Heineman MJ, Leij LF, Schuiling G. 2000. The immune response during the luteal phase of the ovarian cycle: a Th2-type response, Fertil Steril., 74: 1008-1013.

Feuring M, Christ M, Roell A, Schueller P, Losel R, Dempfle CE, Schultz A, Wehling M. 2002. Alterations in platelet function during the ovarian cycle. Blood Coagulation and Fibrinolysis., 13(5): 443-447.

Hallberg L, Hogdahl AM, Nilsson L, Rybo G. 1966. Variation at different ages and attempts to define normality and Menstrual blood loss-a population study. Acta Obstet. Gynecol. Scand., 45: 320-351.

Harewood WJ, Gillin A, Hennessy A, Armitstead J, Horvath JS, Tiller DJ. 2000. The effects of the menstrual cycle, pregnancy and early lactation on haematology and plasma biochemistry in the baboon (Papio hamadryas). $J$ Med Primatol., 29(6): 415-420.

Kim I, Yetley EA, Calvo MS. 1993. Variations in iron-status measures during the menstrual cycle. Am. J. Clin. Nutr., 58(5): 705-709.

Loraine IA, Bell ET. 1963. Hormone excretion during the normal menstrual cycle. Lancet, 1:1340-1342.

Losos JB, Raven PH, Johnson GB, Singer SR. 2002. Biology. McGraw-Hill: New York; 1207-1209.

Makinoda S, Mikuni M, Sogame M, Kobamastsu Y, Yamada H, Yamamoto R, Fujimoto S, Furuta I. 1996. Erythropoietin, granulocyte-colony stimulating factor, interlukin-1 beta and interlukin-6 during the menstrual cycle. Int. J. Gyanecol. Obstet., 55: 265-271.

Mathur S, Mathur RS, Goust JM, Williamson HO, Fudenberg HH. 1979. Cyclic variations in white cell subpopulations in the human menstrual cycle: correlations with progesterone and estradiol. Clin. Immun. Immunopath., 13: 246-253. 
Pathak NR, Desai CA, Chandwani S.1981. Hematological changes during normal menstrual cycle. Indian J. Physiol. Pharmacol., 25(4): 440.

Pehlivanoglu B, Balkanchi ZD, Ridvanagaoglu AY, Durmazlar N, Ozturk G, Erbas D, Okur H. 2001. Impact of stress, gender and menstrual cycle in immune system: Possible role of nitric oxide, Arch Physiol. Biochem., 109: 383- 387.

Pohle FJ. 1939. The blood platelet count in relation to the menstrual cycle in normal Women. Am J. Med., 197: 4047.
Rajnee VK, Chawla RC, Bijendra K, Binawara SC. 2010. Haematological and electrocardiographic variations during menstrual cycle. Pak J. Physiol., 6(1): 18-21.

Simmons BH. 1997. Microcytic Hypochromic Anemias in Hematology: A Combined

Weschler T. 2002. Taking Charge of Your Fertility. HarperCollins: New York; 47-36

Young B. 2006. Wheater's Functional Histology: A Text and Colour Atlas $\left(5^{\text {th }}\right.$ edn). Elseveir Health Sciences; 359. 